\title{
From Crèches to Childcare: constructions of motherhood and inclusion/exclusion in the history of Belgian infant care
}

\author{
MICHEL VANDENBROECK
}

Ghent University, Belgium

\begin{abstract}
In this article the author highlights some elements of the history of exclusion in Belgian infant care and how it is underpinned by constructions of motherhood. In a Belgian context, infant care means institutional care for children from birth to the age of three, funded by the Family and Health Department, in contrast to and entirely separated from pre-school for children aged three to six years, funded by the Education Department (Organisation for Economic Cooperatin and Development [OECD], 2001). The author does this from a hermeneutical historical point of view. As Escolano (1996) has claimed, this means that by means of the evaluation of the internal coherence of the stories (the organisation of data and discourse) and their external coherence with the social context and with other concordant or discordant stories, the author tries try to understand ideas and representations that may help explain the growing exclusion in Belgian infant care.
\end{abstract}

The day care centres emerging in Belgium 100 to 150 years ago, as in France, were designed for women working in factories, that is, for the lowest socioeconomic class in society. Today, one century later, precisely those groups are excluded from this public service for children and families. A closer examination of this history of exclusion helps in the understanding of presentday discourses on childcare and its place in the western European welfare society. It also shows how policy and research are influenced by dominant discourses and are in turn influencing daily practice (McGurck et al, 1993). Historical research in this sense can function as 'a form of critique for ourselves' (Tobin et al, 1989) and reveal hidden assumptions and social constructions (Hendrick, 1997) that underpin exclusion. In doing this, I draw on three sources. The first is social constructionism and Foucault's ideas about power (Foucault, 1975, 2001; Deleuze, 1986; Moss et al, 2000). The second is 
my own historical research on Belgian infant care and the third is some data on the attendance of publicly funded day care in Flanders, drawn from research by Antwerp University (Storms, 1995; see also Vandenbroeck, 2001). Historical research can explain social inequality in infant care as a result of combined influences from psychological science and economy on childcare policy. The history of this social exclusion is a striking illustration of the idea from Foucault that discourse is produced by power (and knowledge) and in its turn produces power and knowledge (Deleuze, 1986).

Traditionally, research about early childhood education (including historical research) has been embedded in a construction of childcare as a societal service to facilitate female employment. The globalisation of the economy has diminished the power of nation states: governments today can exert very little influence on employment in their countries and therefore concentrate on creating the necessary conditions to persuade employers to relocate in their territory rather than in their neighbours' (Dahlberg et al, 1999). This is an example of 'the blurring of boundaries through economic changes' (Popkewitz, 2000). In this perspective government policy may focus, for instance, on tax reductions for employers, on education (to provide a skilled labour force) and on childcare as a condition either to promote academic success or to facilitate skilled female workers to join the labour force. In this vein, globalisation has indirectly reinforced the economic function of childcare as the dominant paradigm. As a consequence, research on childcare is also embedded in this paradigm. Historical research on childcare traditionally describes it in terms of a series of discontinuities and breaking points, according to the role these services fulfil for female employment.

One important break that is often described is that between the medical and hygiene approach on the one hand and the psychological paradigm on the other, with the end of the 1960s and 1970s as a discordant hinge period. The general conclusion is, from that time on, thanks to new psychological insights and the feminist movement, childcare centres on the European continent were open to parental influence, policy became more friendly toward female labour, and the quality of the centres improved (Mozère, 1992; Humblet, 1998). Research from a developmental perspective, on the other hand, such as the research from the National Institute of Child Health and Human Development (NICHD), focuses on academic achievement and non-compliance as outcomes and also on the relationship between childcare and female employment (Belsky, 2001). In the NICHD research a large cohort of women and their children is studied and the focus is effects of infant care, while controlling many possible 'third variables' such as educational level of the mother and poverty (Belsky, 2001; Vandell, 2002). Outcomes of academic skills such as literacy and factors of non-compliance such as aggressive behaviour are the focus. This paradigm (both in historical and in developmental research) hides the effects of discourses about childcare on unemployed or marginalised groups. Hermeneutic research, as I described it, does exist about kindergarten and primary school, but is scarce in the domain of the public education of infants, at 
least in Belgium. This is problematic as Belgian childcare, since its origin, has developed entirely outside the educational system and has therefore - in contrast to the kindergarten or the salles d'asile in France - never been influenced by the educational discourse of Fröbel, Pestalozzi and others.

\section{Hygienic Prevention and Mental Health}

In the late nineteenth and early twentieth centuries the first infant care centres were established in Belgium at the initiative of bourgeois philanthropic groups and were inspired by the French model. They were based in the cities and in the vicinity of the new factories that employed women and therefore installed a separation between working and living environment (Scholliers, 1995). The infant care was designed as a 'machine', which is an infinite series of details that affect daily life and in this way controls behaviour as well as thoughts (Foucault, 1975) to combat infant mortality as well as to facilitate (cheap) female labour. It was therefore regarded as a 'necessary evil' for the labouring class. Governmental officials, moreover, clearly stated that childcare could by no means have an educational policy, as kindergarten had (for instance, Velge, 1940). The emergence of this form of infant care took place in a period of industrialisation that enhanced the (economic) value of physical health (Foucault, 1975). It was marked by the rising popularity of eugenetic and Darwinist sciences, which received scientific status from the emerging statistical approach to science. Together with the abolition of child labour, this constructed the image of the 'fragile child' (Hendrick, 1997) as an investment in the future of the nation and an image of the mother with a dual responsibility. In the eugenetic framework the 'fragile child' was a metaphor for the 'fragile race' that had to be safeguarded for the sake of the nation's future: '[La crèche] est nécessaire dans le présent et elle s'impose dans l'avenir, pour assurer au pays une race belle et forte' (The crèche is necessary in the present as it will be in the future, to safeguard a sound and beautiful race for our country) (Plasky, 1910 , p. 31). Hence, the mother was responsible both for the physical survival of her (decontextualised) child as well as being responsible for the future of society (the nation state). In that sense, child mortality became a public offence of the (decontextualised) mother toward the society and this discourse legitimated far-reaching intrusions of bourgeois private philanthropic organisations into family affairs. There was a tension between the bourgeois need for female labour and their desire to 'educate' the women of lower socioeconomic groups on the one hand, and the dominant idea of the mother as the sole educator on the other hand. This tension was clearly expressed in official texts of that time. Most infant care centres wished to control the poverty as well as the morality of their clients: 'On n'y admet que les enfants âgés de moins de 3 ans dont les mères sont pauvres et se conduisent bien' (One only accepts children under the age of three from mothers that are poor and behave well) (Lecointe et al, 1899, p. 14). It was common practice that the philanthropic organisation responsible for infant care did home visits to check 
on the 'morality' of the mother and to make sure she was not using day care for her own benefit (whatever this meant). Other dynamics have to be considered to understand the dramatic increase in bourgeois philanthropic as well as religious organisations for the poor. It is clear that these charity organisations represented one of the only possibilities for women to take up a leading role in society and enabled them to combine a feminist perspective with bourgeois morale. It was also clear that the female pioneers of this period had a profound and sincere concern about their social mission, as Luc (1997) showed in his doctoral thesis on these institutions and their actors in France. This was also the case with the Belgian pioneers (De Weerdt, 1993).

The first legislation on infant care in Belgium was eloquent by its silence about the tension between the need for childcare and the ideology of the mother: it was meant to legitimise funding of day care centres, but they were never mentioned as such in the legislation. Furthermore, private day care in the home of the carer (one would say family day care providers nowadays) became an 'illégalisme': a common practice that became illegal by legislation, although the legislation could not prevent it from happening (Foucault, 1975), and all legislative texts were profoundly sceptical toward the educational capacities of people from the labouring class.

In most western European countries women played a significantly more active role during the First World War, as they often replaced the male working force in industry. This was much less the case in Belgium, since the heavy industry was almost entirely dismantled by the Germans and unemployment was extremely high. Belgian feminist historians such as De Weerdt (1993) and Courtois et al (1989) regard this as one of the reasons why Belgian women did not obtain the right to vote as early as their European sisters (De Weerdt, 1993). However active women were in the charity organisations in this period did not really influence their societal role afterward.

In the late 1950s, infant mortality decreased dramatically, which meant that infant care and parent support programmes lost their societal and economic legitimacy. It was the human sciences in general, and developmental psychology in particular, that provided a new legitimacy. The World Health Organisation promoted the concept of mental health, replacing and expanding the previous concept of (physically oriented) health. As for the physical health prevention approaches (hygienic programmes), the mental health programmes where first promoted by medical specialists and only later by psychologists, using medical frames of reference (for example, attachment theories). The new scientifically valued discipline of psychology (that drew upon Darwinist biology and statistics for its status) delivered a new and even stronger legitimacy for the intrusion of the upper classes into lower-class childcare and education. The 'fragile child' became 'psychologically fragile' and the 'potentially ill' child was now 'potentially unhappy, frustrated, retarded or delinquent'. A spectacular growth of early screening methods as well the popularisation (and vulgarising) of psychological thinking in women's magazines and television programmes followed (see, for instance, the popularity of programmes with experts such as 
Brazelton in the USA, Winnicott in the United Kingdom and Dolto in France). The construction of the 'psychologically fragile child' rapidly became dominant and shifted toward the concept of a 'predictable child', as De Winter (1986) has shown in his historical research. This was in no way contradictory to the (previous) 'physically fragile' child. A typical example of this is the discussion in the 1970s about the compartmentalisation of children in day care according to their age. The Belgian government appointed two independent commissions of experts to examine this question: one of physicians and one of psychologists (Nationaal Werk voor Kinderwelzijn, 1973). Both groups reported that the children had to be divided into three age groups: one for babies, one for toddlers and one group in between. The medical experts argued this choice because they could identify three stages in the degree to which children were vulnerable to infections: a high-risk group (babies), a low-risk group (toddlers) and a group in between. The psychologists discovered three distinctive groups as far as the 'needs' of children were concerned, according to their motor, psychological and social development. This example (along with many others) showed that the experts' discourses on children were very similar in the medical sciences and the social sciences during the 1960s and 1970s. They shared a common perspective of decontextualised and normalised development and of the use of tests and statistical measurements. They also shared ideas about the impact of early years on later development and, finally, on the dominant role of the mother in development. For instance, the debates about mothers' milk and mothers' affection were two similar and complementary discourses among physicians and the leading psychologists. Both disciplines had similar critical judgements of the mothering capacities of lower-class people and shared opinions about the negative effects of childcare on the development of infants. They also shared a common view on children's (and mothers') needs, that were in fact projections of bourgeois values rather than 'objective' observations (Woodhead, 1997). Feminist scholars such as Singer (1993) and Burman (1994) have pointed at another similarity, namely, the fact that science was very male-dominated.

As a result of this evolution, the (still decontextualised) mother was made even more responsible than ever toward her child as well as toward society. She became more and more responsible for school failure, adolescent delinquency, substance abuse, and so on. This socially constructed image of the fragile, 'cellular' (Foucault, 1975) and predictable child and the responsible mother contributed strongly to what De Winter et al (1999) have labelled the 'educational gap' associated with a perceived moral decay of youth. By this educational gap they meant that a general educational problem (i.e. juvenile delinquency) was perceived as a result of failing families, while the youngsters themselves disagreed with this and pointed to the absence of other caring adults outside the family. 


\section{Exclusion}

From the mid-1960s and even more in the 1970s, female labour changed dramatically. Before the Second World War, female workers had very little formal education and worked in factories or were unemployed. By the late 1960s they had secondary school or higher diplomas and worked in the rapidly growing tertiary sector, for example, in administration, trade, education, tourism and other services. It is evident from official documents regarding childcare (such as governmental reports) that in this period the rise in the socioeconomic class of the users of day care went hand in hand with a more positive discourse on childcare. The writings of the (middle-class) Belgian feminists in this period depicted childcare as a means of accessing the labour market (De Smet et al, 1978). Since then, the 'necessary evil', childcare, has been regarded as an accepted necessity, much less because of the influence of psychologists than because of the mere socio-economic status of its users. As a result, the feminist movements won their case and new budgets were invested in childcare. Figure 1 shows how in just a few years childcare grew tremendously in capacity.

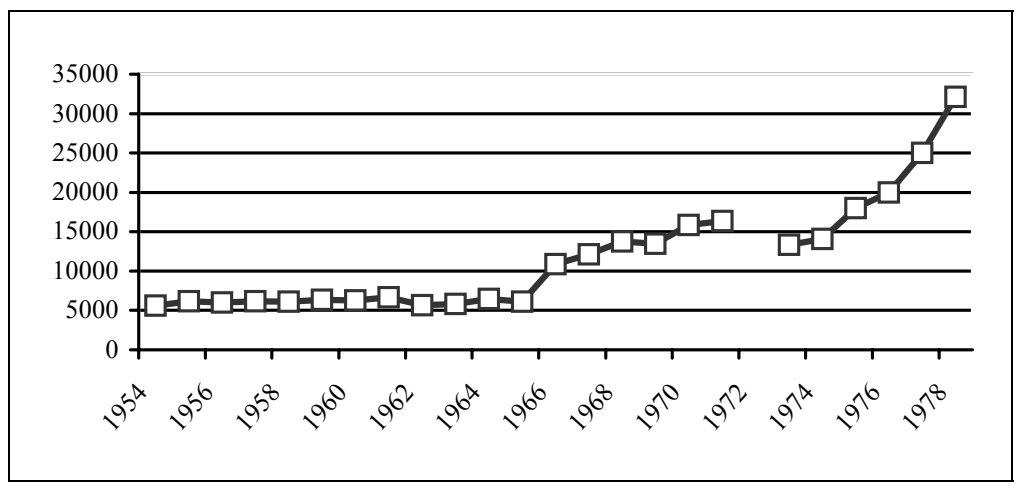

Figure 1. Number of children aged 0-3 in day care centres.

Source: Annual reports of NWK 1954-1978. (The data for 1972 are missing and the data for 1976 and 1977 are approximations. Between 1971 and 1973 a new registration was introduced by the governmental organisation responsible for childcare, resulting in an apparent decrease in the number of children.)

The massive investment of public funds in infant care in the 1970s was consistent with an evolution of dominant ideas about the growing role of the state in welfare provision in most western European countries. The new legislation on Belgian infant care has to be considered in this context. From 1970 to 1975 a whole series of legislative texts were passed, giving local childcare initiatives a right to public subsidies for their staff costs. Before this, public funding was allocated on the condition that parents had an extremely low income, based on a liberal concept of the welfare state, and as defined in 
the typology of Esping-Andersen (1990). The new legislation was a step toward a more social-democratic view of the welfare state, but led to a slowly but irreversibly growing intake of middle-class double income families. In the mid1970s the economic recession (that lasted until the end of the 1980s) caused unemployment to increase dramatically in all industrialised countries. The 'losers' in this economic crisis were in main the (low-educated) man, and the 'winners' of this period were (mostly higher-educated) women. Together with this economic and demographic evolution, the discourse on the public function of childcare changed. In psychological research of that period, the focus was heavily on the compensatory function of pre-school services for the groups 'at risk' and there was an increasing effect of this developmental research on policy-makers (Woodhead, 1988). At the same time, internationalisation of the economy and the feminist movement drove policy-makers toward seeing childcare as a tool for the employment of highly educated female workers. This double function is represented in all legislative texts since 1970, giving public childcare an ambivalent function: allowing middle-class and upper-class women to go to work, and compensating the education of children in lower-class families.

During the 1980s the economic crisis forced governments to cut the expense of the welfare system in general and of infant care in particular. In Flanders, this led to a decade-long halt to the expansion of infant care. At the same time advice from developmental psychology (such as Van Ijzendoorn et al, 1998), drawing on attachment theory, favoured well-planned and full-time care. The rationale behind this discourse was the quality of the relationship between carer and infant (or carer and parent), with a focus on well-guided transition from the home to the centre and on the regularity of the care. Legislative texts as well as internal regulations of centres in the 1980s and the 1990s showed an increasing exclusion of immediate (urgent) care, flexible care and part-time care at irregular times, exactly the types of care that marginalised families might have needed (Verreydt, 1986; Vandenbroeck, 2001).

\section{Management and the (Global) Market}

In this period the tension remained between the psychological discourse that was dominated by attachment theories and the impact of the growing number of mothers at work and children in infant care (Singer, 1993). There is much to say about how individual mothers as well as policy-makers deal with this opposition. One of the political solutions of this tension was to invest in day care that reproduced the family value system (family day care providers or childminders). Another was to adopt the quality approach that was developed in industry and applied to civil services in the 1980s (Dahlberg et al, 1999). The market terminology derived from the profit sector became very popular in welfare institutions in the 1990s. One of the reasons for its popularity was the threat of budget cuts, and the desire of welfare organisations to legitimise their existence in economic terms. Many scholars, such as Popkewitz (2000) and 
Hultqvist \& Dahlberg (2001), have shown how globalisation affects the discourse on early childhood. The discourse of psychology has slowly been taken over by a discourse in management terms. Quality labels are developed in European childcare, mostly inspired by American research such as Thelma Harms's rating scales. In Flanders, from 1994 on, a new quality measurement scale that claimed to be universal was introduced, followed by other similar instruments (Verhegge, 1994). These instruments were a response to the need for governmental control in a decentralised, global-oriented market, as well as to the growing insecurity of parents-as-consumers about their 'predictable child'. They tended, however, to devalue parental ethnotheories on what is good for children, and replaced them with the authority of science. From that moment, 'quality' became what quality scales are measuring, just as 'intelligence' could be defined as that which IQ tests measure. In Flanders, this has meant that accessibility was not a quality criterion, since it was not introduced in the quality assessment instrument. It was a decontextualised and deculturalised quality concept, which did not take into account any social functions of infant care and had no concern for cultural or economic context. In this vein, managerial discourse was a fluent continuation from the decontextualised psychological discourse on the mother-child dyad. The managerial discourse did not alter the image of the psychologically fragile child, or that of the responsible mother. On the contrary, it enhanced the responsibility of motherhood, but now focused on her as a client, protected by (and thus dependent on) the quality label and the expert's opinion. Regrettably, the participation of parents as citizens and as co-constructors (Dahlberg et al, 2000) of infant care becomes impossible in a system where quality is universally defined.

Valuing the economic function of childcare in the 1980s and 1990s has gone hand in hand with a devaluation of its social function. In the mid-1990s, a major survey of nearly 4000 families was conducted at the University of Antwerp. The research showed that nowadays it is primarily the higher income group that uses childcare - no less than $60 \%$ of families with children under the age of three years, while they comprise only $36 \%$ of the population. Conversely, only $20 \%$ of families with the lowest income (which comprise $41 \%$ of the population) use public-funded childcare. The social segregation remains even when controlled for employment (Storms, 1995). In contrast, over $98 \%$ of all children aged three years attend kindergarten in Belgium. Previous research (Vandenbroeck, 2001), as well as yet incomplete and preliminary results of an ongoing survey in 82 day care centres in Brussels, showed that the exclusion is due largely to internal regulations of day care centres. The intake regulations necessitate long-term planning on the part of the parents and favour regularity of care. Those are now two conditions for acceptance in the centres that are legitimised by popular psychological literature, but are difficult to meet for parents with precarious job situations. On top of this socio-economic segregation comes cultural discrimination for specific ethnic minority groups that are both overt (i.e. language of the parents as a selection criterion) and 
covert (i.e. monocultural staff and uniform educational practices that are perceived as universal quality education). These internal discriminatory practices are justified by legislation that allows the economic function of childcare to prevail in its social function and reduces the child to a psychologically determined being, without taking his or her social or cultural context into account.

\section{A Consideration on the Educational Philosophy}

In the pioneer days Belgian infant care was a private initiative that can be viewed from a liberal economic point of view (female labour force), from a eugenetic point of view (preserving the health of the nation), from a social point of view (preventing social uproar in the labouring class), as well as from a feminist point of view (that was shared by some of the pioneers). It has resulted in a system of care that was shaped entirely outside the educational discourse and that constructed (and was constructed by) a specific image of a responsible mother. In the 1970s childcare grew dramatically, but the strong division between education and care was maintained and legislation clearly prohibited a cooperation between infant care (0-3 years) and pre-school (3-6 years). Since the 1960s the rise of educational discussions in infant care has added to the previously prevailing medical concern. There was, after all, a growing concern about the youngest child's well-being, its development and its emotional state of mind. Educational debates were introduced during the 1970s in Belgian infant care, including the way adults talked to children, the play materials offered, the autonomy of the child that was (or was not) respected. However, from present-day hindsight, this educational discourse appears to be an applied developmental psychology. My research shows that an educational philosophy that is merely based on psychological knowledge of children is insufficient to construct childcare, since it offers no social, economic or political frame of reference. Therefore, while the 'quality' (if we are still to use this term) of infant care has undoubtedly and dramatically increased in recent decades, as comparative research on large-scale observations shows (Peeters, 1993), at the same time its social mission has vanished. This analysis is consistent with research in other European countries and other areas of infant care, such as family day care in the United Kingdom (for instance, Dillon et al, 2001). It shows the relevance of the analysis of Gilles Brougère \& Sylvie Rayna (1998): 'We question early childhood policy, not so much in order to dress a picture of it, but rather to show how these policies have a cultural background. The role of the state is not to be seen as independent from representations of the child, the family or women in society' (p. 5; my translation). 
Correspondence

Michel Vandenbroeck, Resource Centre for Childcare - VBJK, Department of Social Welfare Studies, Ghent University, Dunantlaan 2, B-9000, Ghent, Belgium (michel.vandenbroeck@ugent.be).

\section{References}

Belsky, J. (2001) Developmental Risks (Still) Associated with Early Childcare, Journal of Child Psychology and Psychiatry, 42, pp. 845-860.

Brougère, G. \& Rayna, S. (1998) Culture et innovation dans l'éducation préscolaire, in G. Brougère \& S. Rayna (Eds) Culture, Enfance et Education Préscolaire [Culture, Childhood and Preschool Education], pp. 5-44. Paris: Université Paris Nord-INRPUNESCO.

Burman, E. (1994) Deconstructing Developmental Psychology. London: Routledge.

Courtois, L., Pirotte, J. \& Rosart, F. (1989) Femmes des années 80. Un siècle de condition féminine en Belgique. 1889-1989. Louvain-la-Neuve: Academia.

Dahlberg, G., Moss, P. \& Pence, A. (1999) Beyond Quality in Early Childhood Education and Care. London: Falmer Press.

Dahlberg, G., Moss, P. \& Pence, A. (2000) Getting beyond the Problem with Quality. European Early Childhood Educational Research Journal, 8, pp. 103-155.

Deleuze, G. (1986) Foucault. Paris: Les Editions de Minuit.

De Smet, C., Proesmans, R., Stasse, I. \& Van Mechelen, R. (1978) Kleine kinderen, grote zorgen. Gent: Lef-Masereelfonds.

De Weerdt, D. (1993) De vrouwen van de Eerste Wereldoorlog. Gent: Stichting Mens en Kultuur.

De Winter, M. (1986) Het voorspelbare kind. Vroegtijdige onderkenning van ontwikkelingsstoornissen in wetenschappelijk en sociaal-historisch perspectief. Lisse: Swets \& Zeitlinger.

De Winter, M., Kroneman, M. \& Baerveldt, C. (1999) The Social Education Gap Report of a Dutch Peer-Consultation Project on Family Policy, British Journal of Social Work, 29, pp. 903-914.

Dillon, J., Statham, J. \& Moss, P. (2001) The Role of the Private Market in Day-Care Provision for Children in Need, Social Policy and Administration, 35, pp. 127-144.

Escolano, A. (1996) Postmodernity or High Modernity? Emerging Approaches in the New History of Education, Paedagogica Historica, XXXII, pp. 325-341. Gent: Universiteit Gent.

Esping-Andersen, G. (1990) The Three Worlds of Welfare Capitalism. Cambridge: Polity Press.

Foucault, M. (1975) Surveiller et punir. Paris: Gallimard.

Foucault, M. (2001) L'Herméneutique du sujet. Cours au Collège de France. 1981-1982. Paris: Seuil/Gallimard.

Hendrick, H. (1997) Constructions and Reconstructions of British Childhood: an interpretative survey, 1800 to the present, in A. James \& A. Prout (Eds) Constructing and Reconstructing Childhood, pp. 34-62. London: Falmer Press. 
Hultqvist, K. \& Dahlberg, G. (2001) The Changing Child in a Changing World. London: Routledge.

Humblet, P. (1998) Analyse et évaluation de la mise en oeuvre du programma de l'Oeuvre Nationale de l'Enfance pour les milieux d'accueil de jeunes enfants. Doctoral thesis. Brussels: Faculté de Médecine, ULB.

Lecointe, A., Bouchery, A., Van Wijnendaele, N., Pede, N., Duclos, N. \& De Schepper, C. (1899) Crèche Louise-Marie. Statuts et règlements. Arrêtées en Assemblée Générale le 16 février 1899. Ostende: Imprimerie Bouchery.

Luc, J. (1997) L'invention du jeune enfant au XIXe siècle. De la salle d'asile à l'école maternelle. Paris: Belin.

McGurck, H., Caplan, M., Hennessy, E. \& Moss, P. (1993) Controversy, Theory and Social Context in Contemporary Day Care Research, Journal of Child Psychology and Psychiatry, 34, pp. 3-23.

Moss, P., Dillon, J. \& Statham, J. (2000) The 'Child in Need' and 'the Rich Child': discourse, constructions and practice, Critical Social Policy, 20, pp. 233-254.

Mozère, L. (1992) Le printemps des crèches. Histoire et analyse d'un mouvement. Paris: L'Harmattan.

Nationaal Werk voor Kinderwelzijn. (1973) Werkverslag van de commissie der kribben en peutertuinen. Intern document. Brussels: NWK.

National Institute of Child Health and Human Development (NICHD) Early Child Care Research Network (1993) The NICHD Study of Early Child Care: a comprehensive longitudinal study of young children's lives. ERIC Document Reproduction Service No. ED 3530870.

Organisation for Economic Cooperation and Development (OECD) (2001) Starting Strong. Early Childhood Education and Care. Paris: OECD.

Peeters, J. (1993) Quality Improvement in the Childcare Centres, in R. Baekelmans, F. Laevers, J. Peeters, A. Somers \& M. Vandenbroeck (Eds) Working towards Better Childcare. Report over Thirteen Years of Research and Training with the Support of the Van Leer Foundation and Child and Family, pp. 45-84. Gent: RUG-VBJK.

Plasky, E. (1910) La crèche et sa nécessité sociale. Conférence donnée le 5 février 1910 à l'Exposition d'Hygiène des enfants du premier âge. Anvers: Buschmann.

Popkewitz, T. (2000) Educational Knowledge. Changing Relationships between the State, Civil Society, and the Educational Community. Albany: State University of New York.

Scholliers, P. (1995) A Century of Real Industrial Wages in Belgium, 1840-1939, in P. Scholliers \& V. Zamagni (Eds) Labour's Reward: real wages and economic change in 19th and 20th century Europe, pp. 106-137. Cheltenham: Edward Elgar.

Singer, E. (1993) Shared Care for Children, Theory and Psychology, 3, pp. 429-449.

Storms, B. (1995) Het mattheüs-effect in de kinderopvang. Antwerpen: Centrum voor Sociaal Beleid-UIA.

Tobin, J., Wu, D. \& Davidson, D. (1989) Preschool in Three Cultures: Japan, China and the United States. New Haven: Yale University Press.

Vandell, D. (2002) Early Childcare and Children's Development Prior to School Entry: results from a NICHD study of early childcare, American Educational Research Journal, 39, pp. 133-164. 
Vandenbroeck, M. (2001) The View of the Yeti. bringing up children in the spirit of selfawareness and kindredship. The Hague: Van Leer Foundation.

Van Ijzendoorn, M., Tavecchio, L., Stals, G. \& Reiling, E. (1998) Quality of Center Day-Care and Attunement between Parents and Caregiver: center day-care in cross-national perspective, Journal of Genetic Psychology, 159, pp. 437-454.

Velge, H. (1940) De bedrijvigheid van het Nationaal Werk voor Kinderwelzijn tijdens vijf en twintig jaar (1915-1940). Brussels: NWK.

Verhegge, K. (1994) De beoordelingsschaal voor het pedagogisch functioneren in kinderdagverblijven. Brussels: $\mathrm{K} \& \mathrm{G}$.

Verreydt, G. (1986) Kinderopvang in de provincie Antwerpen. Beschrijving van het aanbod en de participatie aan voorzieningen voor kinderopvang, Het Kind, 1, pp. 15-26.

Woodhead, M. (1988) When Psychology Informs Public Policy. The Case of Early Childhood Intervention, American Psychologist, 43, pp. 443-454.

Woodhead, M. (1997) Psychology and the Cultural Construction of Children's Needs, in A. James \& A. Prout (Eds) Constructing and Reconstructing Childhood, pp. 63-84. London: Falmer Press. 